\title{
Money growth and social stability
}

\author{
Erdem BASCI
}

TED University, Ankara, Turkey

Sidika BASCI

\author{
Ankara Yildirim Beyazit University, Turkey \\ Tahar GHERBY \\ EISTI, Cergy, France
}

Received: 15.07.2021, Revised: 01.11.2021, Accepted: 26.01.2021

doi: http://dx.doi.org/10.29015/cerem.931

\begin{abstract}
Aim: Both the Keynesian and the Fisherian channels of sovereign money growth have slowed down significantly in the decade following the Global Financial Crisis (GFC). Together with the rise of fintech, privately issued unbacked crypto-assets tried to fill this void. The developments have revived the interest on the Central Bank Digital Currency (CBDC) idea and on developing potential channels for future sovereign money growth. The aim of this paper is to compare the Keynesian and Fisherian channels of sovereign money growth regarding their impact on wealth distribution and inflation.
\end{abstract}

Design / Research Methods: We use a simple monetary model with heterogeneous agents. In our model, the agents are consumers with different spending propensities but with equal initial wealth levels and with exactly the same non-interest incomes over time.

Conclusions / findings: We show that the Keynesian (uniform) money growth channel has a softening effect on the wealth dispersion and thereby, an upward pressure on money velocity. The model implies that the inclusive nature of current post-Covid19 recovery plans may have a desirable impact on social stability. Yet, these plans may turn out to be more inflationary in comparison the post-GFC policies.

Originality / value of the article: This paper shows that heterogeneity of economic agents should not be ignored by post-GFC policy makers and that how new money is created matters in an essential way under heterogeneity of savings behaviour.

\footnotetext{
Correspondence address: Erdem BASCI, TED University, Ankara, Turkey. E-mail: erdem.basci@tedu.edu.tr. Sidika BASCI, Ankara Yildirim Beyazit University, Turkey. E-mail: sidika.basci@gmail.com. Tahar GHERBI. EISTI, Cergy, France. E-mail: tahar.gherbi@gmail.com.
} 
Implications of the research: The implication for policy makers is that the demand deficiency associated with the fall in money velocity and the worsening of wealth dispersion may be softened by a more inclusive money growth regime, potentially with the practical use of CBDCs. Yet, the extra inflationary impact of such a regime needs to be kept in mind.

Key words: Money Velocity, Money Growth, Heterogeneity, CBDC, Wealth Distribution, Sustainable Development Goals, SDG10, Inequalities, Inflation

JEL: D31, E4, E63

\section{Introduction}

The growth rate of broad money supply aggregates has been modest over the decade following the Global Financial Crisis (GFC). This coupled with a several decades long fall in the velocity of money (Basci, Gherbi 2020) seems to have led to a demand deficiency era in most G7 countries (Basci, Basci 2021), until very recently. Yet, following the Covid-19 pandemic shock, the nature of the massive expansionary fiscal, monetary and financial sector policies in especially the United States (English et al. 2021; Carroll et al. 2021) have the potential to reverse this trend in low nominal demand growth towards a more inflationary one (Blanchard, 2021; Goodhart 2020; Summers 2021).

The rise of digitalization and the decline of nominal and real interest rates over the last four decades have made it necessary to rethink about the future of macroeconomic policy. The rise of digitalization paves the way for a more inclusive monetary system. The fall in interest rates opens up fiscal room for more expansionary policies. Yet, both of these opportunities require careful analysis and design considerations before taking any concrete policy action. In this paper we demonstrate that 'agent based modelling' (ABM) is a practical modelling tool for that purpose.

The rise of digital technologies in finance (fintech) combined with moderate growth rates in the quantity broad money aggregates in developed countries have paved the way to the development of privately issued unbacked crypto assets. This development has necessitated innovations in public monetary and financial services provided by the sovereigns as well.

On the fintech side, account-based Central Bank Digital Currencies (CBDC) have come up as an innovative idea that would enable equal access of masses to low 
cost and high quality services offered by sovereign money, simply via their national identification numbers. ${ }^{1}$ On the fiscal side the use of 'checks' mailed directly to the home addresses of citizens as part of massive stimulus packages have become more frequent following the Covid-19 pandemic from early 2020 onwards.

Privately issued unbacked crypto assets are by construction both economically and socially unstable. ${ }^{2}$ Potentially stable alternatives, the so-called 'stable coins,' have to be backed fully by sovereign money if they really are to be stable. In contrast, national currencies issued by sovereign states have shown success regarding price stability, especially over the last four decades. Yet, implications of sovereign money on social stability has been less explored. The focus of this paper, therefore, will be on sovereign money growth channels and their implications on social stability via wealth dispersion.

In the paper, we construct a heterogeneous agent model where sovereign money can grow in one of two regimes. In the Fisherian regime, money grows proportionally to the nominal interest rate which consist of expected inflation and the real interest rate. In the Keynesian regime, money grows via equally distributed transfers to all citizens.

We find by using a simple heterogeneous agent monetary model that the Keynesian channel of money growth may have desirable effects on wealth dispersion, yet it is more inflationary than the Fisherian alternative.

The paper proceeds as follows. Section 2 presents some stylised facts. Section 3 presents the model and the equations. The analytical steady state solutions for the case of two agents are derived in Section 4. The simulation results with transition dynamics for more than two agents are presented in Section 5. Section 6 concludes with some remarks.

\footnotetext{
${ }^{1}$ See BIS (2021: Chapter 3) on potential benefits of account based CBDCs. Opportunities for public authorities from fintech like the recently developed fast payments systems are also discussed here. Once the account based CBDCs are fully in place, there will be no further need for mailing checks to imprecise home addresses by the fiscal authority.

${ }^{2}$ In addition to wild fluctuations in their prices, unbacked private crypto assets are prone to cyber-security risks as well as to use in illicit activities. See BIS (2021: Chapter 3) and the references therein.
} 


\section{Stylized facts}

The first stylised fact is the sustained fall in the velocity of circulation of broad money stock during the last four decades. Velocity of money is defined by the below equation:

$$
M v=P y
$$

where $M$ is the total amount of money in an economy during a given period, $v$ is the money velocity, $\mathrm{P}$ is the price level associated with transactions for the economy during the period and $y$ is the real total income of the economy.

Figure 1. Broad money stock velocity for the U.S.

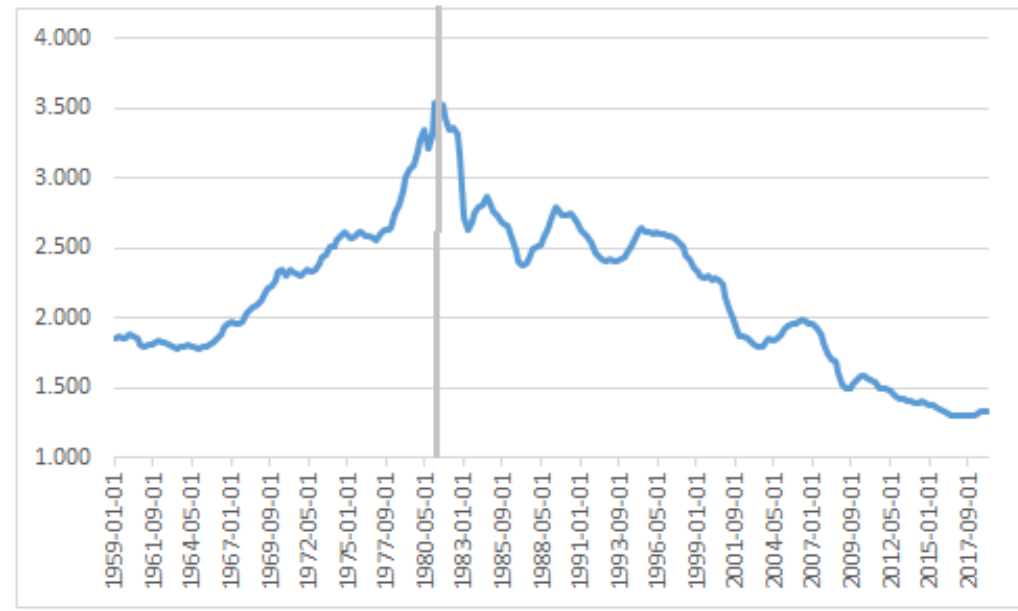

Source: Federal Reserve Bank of St. Louis, https://fred.stlouisfed.org/

Note: Seasonally adjusted quarterly data for the velocity of the broad U.S. money aggregate MZM .

There is a sustained fall in the velocity of U.S. broad money in the recent decades (Figure 1). The structural change is around year 1980, when the Federal Reserve System has started controlling the Federal Funds Rate directly. This was made possible after technological advance in the information and communication technologies, allowing for clearing bank reserves on a daily basis by the Central 
Bank. This operational change of making the short term interest rate the main policy instrument of the central bank, coupled with the independence of the Central Bank, opened up a new era of an unprecedented sustained fall in the velocity of broad money.

Basci and Gherbi (2020) attempt to explain such a sustained fall in velocity in a model with consumer heterogeneity. Yet in that paper, there is no money growth assumed and the data before 1980 is not addressed. In this paper we will argue that the inflationary Keynesian monetary growth regime may have led to a relatively more even distribution of money wealth. Following Fisherian decades of money growth therefore was a transition period to a new steady state with much lower velocity, where money has been accumulated in the hands of high savers.

The second stylized fact in line with the above line of reasoning is the sustained widening of the U.S. wealth dispersion after the 1980s.

Figure 2. Shares of family wealth, by wealth group for the U.S.

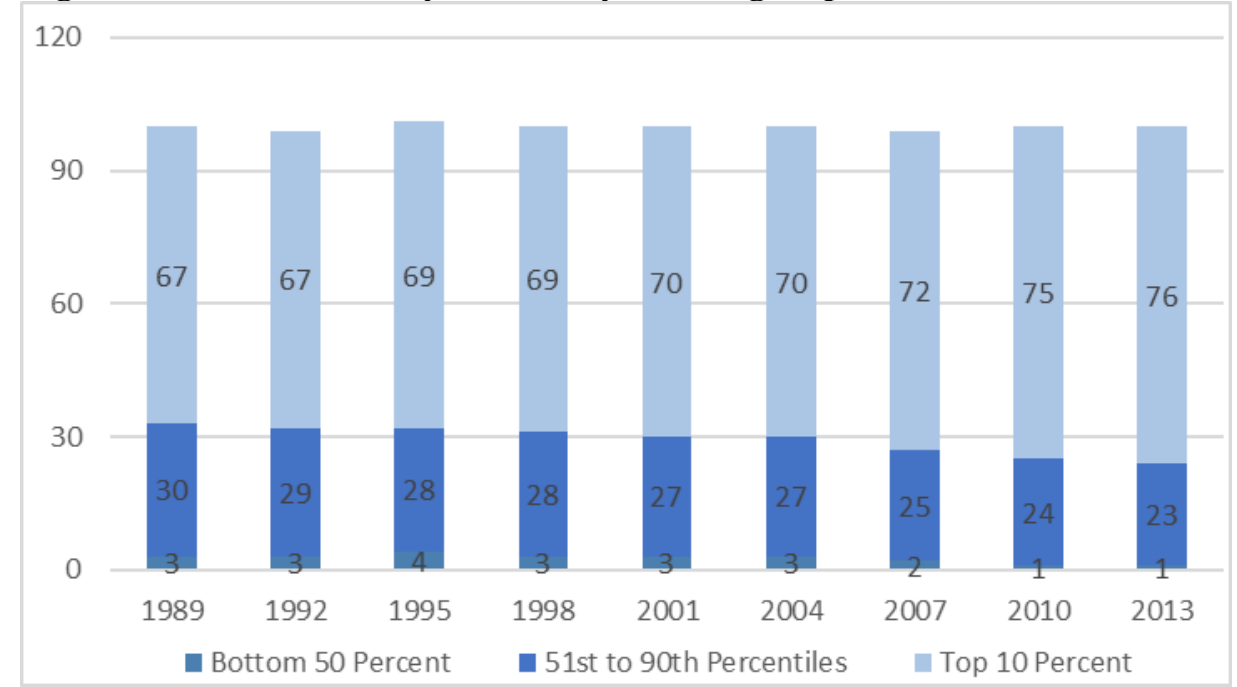

Source: Congressional Budget Office US, Karamcheva (2016).

In Figure 2 above, the trend in concentration of wealth in the top 10 per cent of the population is evident in the US after the end of the 1980s. This is consistent with the fall in velocity of money, as explained in Basci and Gherbi (2020) in a model without money growth. In the current paper, we will argue that the same dynamics 
prevail if money growth is proportional (regardless of what the rate of money growth is). This may explain some of the stylised observations in the post 1980 Fisherian era of monetary policy. Such transition dynamics which are sustained over many years are too important to ignore.

\section{The model}

In our model, the only source of heterogeneity is the savings behaviour of the agents. The agents are consumer-producers with exactly equal initial wealth and equal labour income over time. The wealth can be held in the form of sovereign issued fiat money. We will study two alternative sources of money growth.

In the first case, the stock of money will grow evenly via newly produced cash transfers to all agents. The transfers will be equal per capita. We will call this the Keynesian channel. The thought experiment is originally due to J.M. Keynes, although the following literature called it 'helicopter money.'

In the second case, the stock of money will grow proportionally via newly produced money in the banking system. The transfers will be in the form of interest earned on existing money balances. We will call this the Fisherian channel. This can be attributed to the original work of Irving Fisher (Fisher, 1930) who decomposed nominal interest rates into expected inflation and real interest rate components. ${ }^{4}$

We will assume the presence of $N$ agents. $M$ denotes the total amount of money in the economy. $\left\{M_{1 t}, M_{2 t}, \ldots, M_{N t}\right\}$ is the vector of amounts of money each individual has at time $t . M_{t}=\sum_{i=1}^{N} M_{i t}$ for all t. The budget constraint for agent $i$ at time $t$ is:

\footnotetext{
${ }^{3}$ See Bernanke (2002) citing both J.M. Keynes and M. Friedman in his seminal speech while using the term 'helicopter money' to mean money financed tax cuts. Recently, some prominent European authors began to use the term 'helicopter money' to mean money financed equal transfers to households. See for example Gali (2020a, 2020b) and Martin et al. (2021).

${ }^{4}$ In 1970s the Keynesian channel of money creation has been more dominant. After 1980, the Fisherian chanel has become more dominant under the guidance of independent central banks. See Jilek and Matusek (2010) and McLeay et al. (2014) for post 1980 channels of money creation in the banking system. Jilek and Matusek (2010: 44) spells out interest rate paid on deposits, as one prominent channel for money growth.
} 


$$
M_{i, t+1}=M_{i t}+M T_{i t}-C_{i t}+W_{i t} L
$$

where $M T_{i t}$ is the monetary transfer received at the beginning of time t, $W_{i t}$ is the wage rate, $L$ is working time and $C_{i t}$ is the consumption level of the $i^{t h}$ agent at time $t$. Since initially, money is distributed equally among the agents in the economy, the initial condition is:

$$
M_{i, 0}=M_{0} / N \text { for all } i
$$

We assume that consumption is a linear function of post-transfer money, $P T M_{i t}=M_{i t}+M T_{i t}$ so:

$$
C_{i}\left(P P M_{i 1}\right)=\gamma_{i} P T M_{i t} \quad 0<\gamma_{i}<1 \text { for all } i
$$

where $\gamma_{i}$ is propensity to spend out of money for agent $i$. $C$ is the total nominal demand in the economy. $\left\{C_{1 t}, C_{2 t}, \ldots, C_{N t}\right\}$ is the vector of consumption spending by each individual at time $t . C_{t}=\sum_{i=1}^{N} C_{i t}$ for all t.

The total spending to buy the constant amount of real output, $y$, determines both the price level at time t, via $p_{t}=C_{t} / \mathrm{y}$ and the nominal wage income, which is nominal revenue distributed equally across all agents, $W_{i t} L=C_{t} / \mathrm{N}$. The gross inflation rate is calculated as usual via, $p_{t+1} / p_{t}$.

In both cases, growth rate of total money stock will be taken as the same for comparison purposes. The method of money growth is however different. In the Fisherian case,

$$
M_{i, t+1}=M_{i t}+r M_{i t}-C_{i t}+W_{i t} L
$$

will prevail for all $\mathrm{t}$ and for all $\mathrm{i}$, while in the Keynesian case,

$$
M_{i, t+1}=M_{i t}+r M_{t} / N-C_{i t}+W_{i t} L
$$

will prevail, where $r$ is the growth rate of total money balances in both cases. 


\section{Analytical solution for the case of two agents}

In this section we will study the steady state money shares and the corresponding velocity of money for the Keynesian and the Fisherian money growth regimes.

Let $\mathrm{i}=1,2$ denote agents 1 and 2 . We will assume that, $0<\gamma_{1}<\gamma_{2}<1$. Agent 1 , therefore is assumed to be more patient that agent 2 .

In the case of the Keynesian money growth regime, new money will be divided equally among the two agents:

$$
\begin{aligned}
& M_{1, t+1}=M_{1 t}+r M_{t} / 2-C_{1 t}+W_{1 t} L \\
& M_{2, t+1}=M_{2 t}+r M_{t} / 2-C_{2 t}+W_{2 t} L
\end{aligned}
$$

It will be convenient to work with money shares of the two agents for calculating their steady state values. We will denote the post transfer money share of agent $i$ by,

$$
m_{i t}=\left(M_{i t}+\frac{r M_{t}}{2}\right) /\left((1+r) M_{t}\right)
$$

Substituting for consumption values from (4) and wage income values from $W_{i t} L=C_{t} / 2$ in (5) and (6) and dividing their both sides by the post transfer total money stock, $(1+r) M_{t}$ and rearranging, we obtain the two equations for the evolution of money shares:

$$
\begin{aligned}
& (1+r) m_{1, t+1}=\frac{r}{2}+\left(1-\frac{\gamma_{1}}{2}\right) m_{1 t}+\frac{\gamma_{2}}{2} m_{2 t} \\
& (1+r) m_{2, t+1}=\frac{r}{2}+\left(1-\frac{\gamma_{2}}{2}\right) m_{2 t}+\frac{\gamma_{1}}{2} m_{1 t}
\end{aligned}
$$

It is easy to verify that the money shares always add up to one, the above system of equations is stable and the steady state value of the less patient consumer (agent 2), $m_{2 s}$ can be calculated as: 


$$
m_{2 s}=\frac{r+\gamma_{1}}{2 r+\gamma_{1}+\gamma_{2}}
$$

Taking the derivative with respect to $r$ we get:

$$
\frac{d m_{2 s}}{d r}=\frac{\left(2 r+\gamma_{1}+\gamma_{2}\right)-2\left(r+\gamma_{1}\right)}{\left(2 r+\gamma_{1}+\gamma_{2}\right)^{2}}
$$

or,

$$
\begin{gathered}
\frac{d m_{2 s}}{d r}=\frac{\left(\gamma_{2}-\gamma_{1}\right)}{2 r+\gamma_{1}+\gamma_{2}}>0 \\
\text { since } 0<\gamma_{1}<\gamma_{2}<1 .
\end{gathered}
$$

The steady state value of the less patient consumer's money share, therefore is an increasing function of the money growth rate, $r$. Since $m_{1 s}+m_{2 s}=1$, the steady state value of high saving consumer is a decreasing function of money growth. Hence a Keynesian inflation has a softening effect on the wealth distribution arising from heterogeneous savings.

The velocity of circulation of post transfer money stock defined through equation (1) can be calculated for the steady state solution as follows.

$$
v_{t}=\frac{Y_{t}}{(1+r) M_{t .}}=\frac{C_{1 t}+C_{2 t}}{(1+r) M_{t}}
$$

Substituting for respective nominal consumptions from (4) and rearranging for money shares of the two agents, we obtain the velocity in a simplified form:

$$
v_{t}=\gamma_{1} m_{1 t}+\gamma_{2} m_{2 t}
$$

Using $m_{1 t}+m_{2 t}=1$ we obtain,

$v_{t}=\gamma_{1}+\left(\gamma_{2}-\gamma_{1}\right) m_{2 t}$ 
which holds for the steady state value as well. Substituting for the steady state solution for the money share of the less patient consumer (agent 2) and rearranging, we can solve for the steady state value of velocity in the Keynesian money growth regime.

$$
v_{s}=\gamma_{1}+\left(\gamma_{2}-\gamma_{1}\right) \frac{r+\gamma_{1}}{2 r+\gamma_{1}+\gamma_{2}}
$$

The steady state velocity is an increasing function of the money growth rate, $r$ in the Keynesian regime. Therefore the positive distributional effect of inflating the economy this way has a cost of higher inflation in transition to steady state and higher equilibrium prices on the steady state path.

Going through a similar analysis for the Fisherian money growth regime is relatively easier, since the proportional nature of money growth to individual money balances gives rise to a neutrality result. Neither the money shares, nor the transition or the steady state velocity of money are affected by the money growth rate, $r$, under the Fisherian regime. In this case $m_{2 s}=\gamma_{1} /\left(\gamma_{1}-\gamma_{2}\right)$ regardles of the speed of money growth.

In order to observe the transition dynamics in a more crowded economy, in the next section we will present the simulation results from typical runs of our model with more than two agents under the two distinct regimes of money growth.

\section{Simulation results ${ }^{5}$}

For simplicity of demonstration and without loss of generality, the number of agents (i.e. consumers) in the economy, $N$, is taken as 10 . The initial total amount of money in the economy, $M$, is taken as 1000 and by Equation (3), $M_{i 0}=100$ for all i. Therefore, initially all agents have an equal share in liquid assets of 10 per cent. The total real production level, $y$, is taken as 100 real units of consumption goods.

\footnotetext{
5 Results are obtained by using a code written for Python and is available upon request from the authors.
} 
The agents are assumed to be heterogeneous and their marginal propensities to consume (MPC) are generated randomly from a uniform distribution between 5 per cent and 95 percent. This is consistent with a very wide range of MPCs reported in the empirical literature (see for example Carroll et al. 2017).

For comparability of the results in all simulations, the seed of the random variable is assigned the same value in all simulations. The lowest MPC value is 0.075 and the highest MPC value is 0.813 . The most patient agent therefore spends 7.5 per cent of its post-income monetary wealth, while the least patient one spends 81.3 per cent of its monetary wealth. The later can be thought to represent the 'handto-mouth' consumers with very little steady state precautionary money balances in comparison to their income. The rest of the agents have MPC values evenly spread between these two extremes.

\section{Figure 3. Wealth dispersion over agents, Fisherian case}

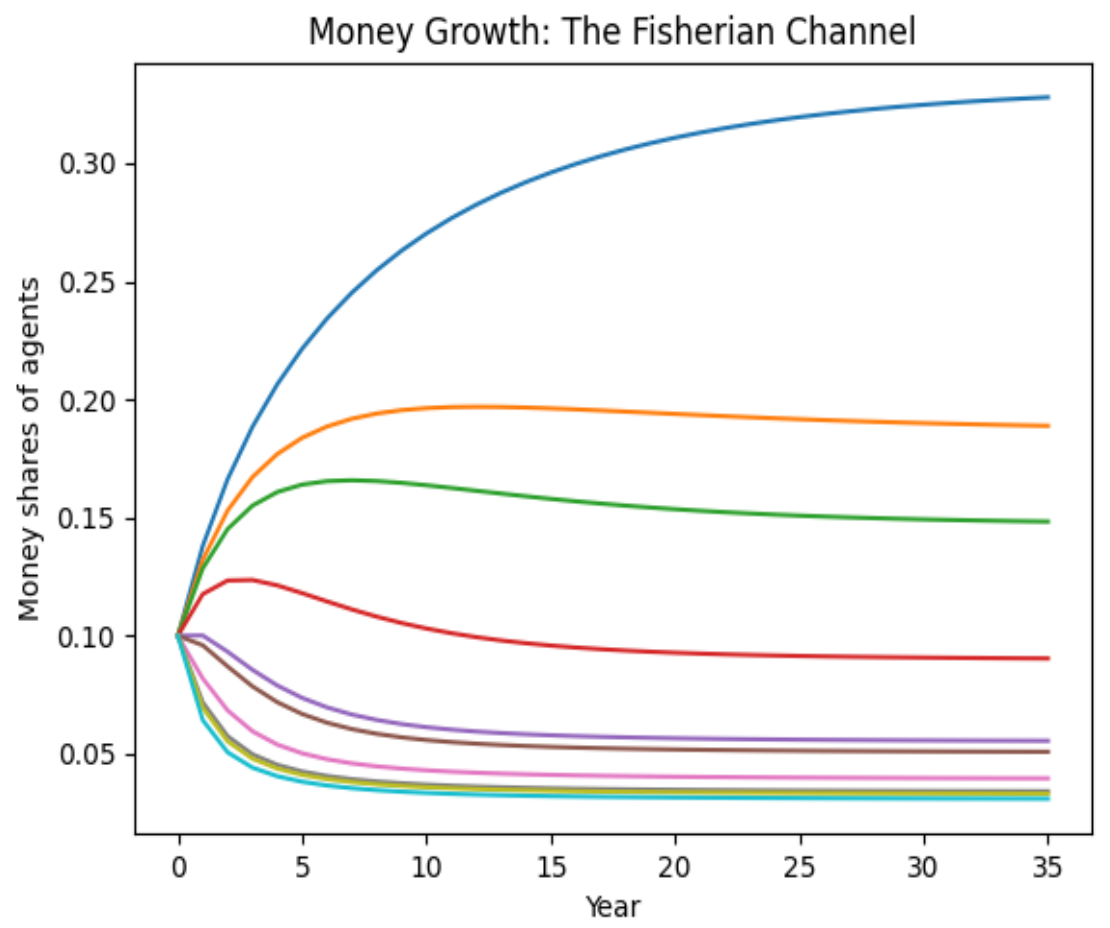

Source: authors' own elaboration 
Figure 3 shows the results for the run the simulation with 10 agents and a constant money growth rate of 7 per cent per annum. As described in Section 3, all agents receive an equal amount of wage income, since they are assumed to be homogeneous regarding their skills and preferences for work. Therefore, the only source of inequality in this paper is the heterogeneity in the consumption and saving propensities of the agents.

The blue line at top shows the rise of the money share of the most patient agent over the years. In contrast, the green line at the bottom shows the decline in the money share of the least patient agent. In this Fisherian case, money grows solely proportionally to the money balances of each agent (at 7 per cent per annum). Therefore, the dispersion between money shares of the top 10 per cent and the bottom 10 per cent savers is quite remarkable.

The total nominal demand grows significantly below the rate of growth of aggregate broad money, especially in the initial years, because of the high savings of the patient agents. As they accumulate more monetary wealth, and thereby get closer to their desired steady state money-to-income levels, their consumption expenditures increase towards their income levels. The total spending growth also approaches the 7 per cent broad money growth. Hence the inflation rate approaches 7 per cent from below, following initial years with a very deflationary bias.

Figure 4 shows the equilibrium path of transition in key macroeconomic variables. The growth rate of broad money is constant at 7 per cent per annum throughout the simulation period. Money grows proportionally to own money balances of each agent, i.e. only the Fisherian channel is activated.

The fall in the velocity of money together with the rise of the share of money holdings of high savers is remarkable. The sharp fall in money velocity, especially in the earlier years, puts a significant amount of deflationary pressure on the inflation rates. Even at a 7 per cent nominal money growth, inflation is pushed into a deeply negative territory in the first year due to a shortfall in aggregate spending. Over time as the wealth distribution approaches a steady state, the inflation rate converges to 7 per cent from below. 
Figure 4. Velocity, inflation and wealth share of top savers: Fisherian case

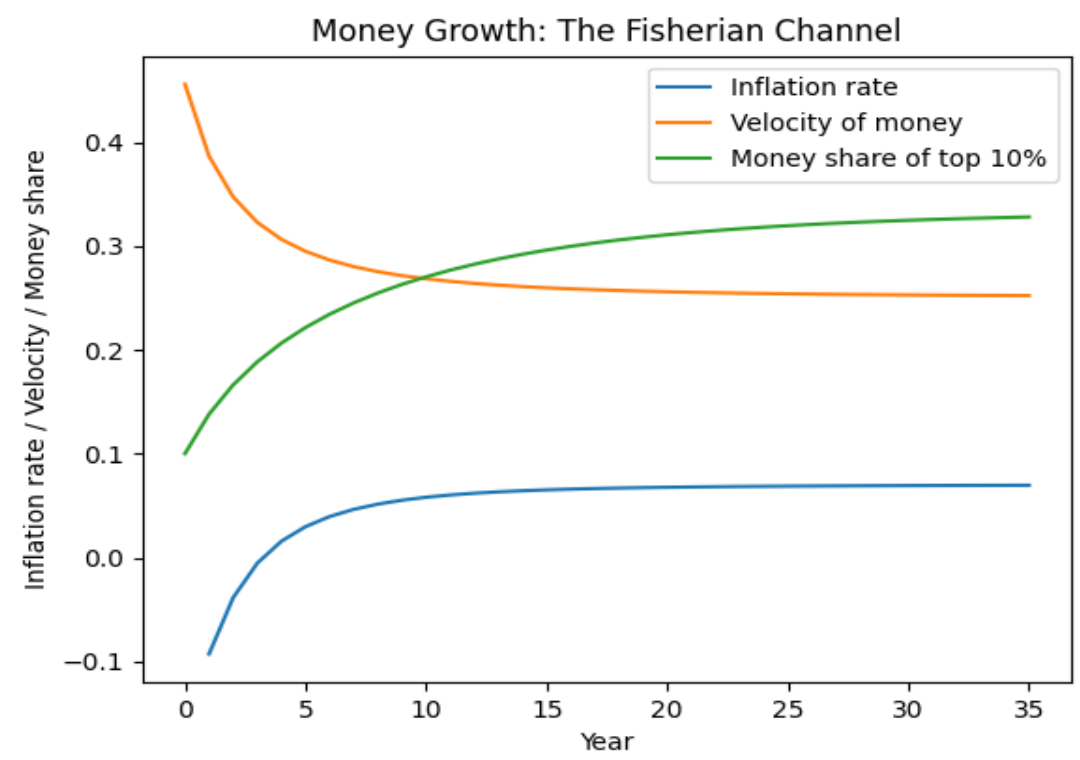

Source: authors' own elaboration

Figure 5. Wealth dispersion over agents: Keynesian case

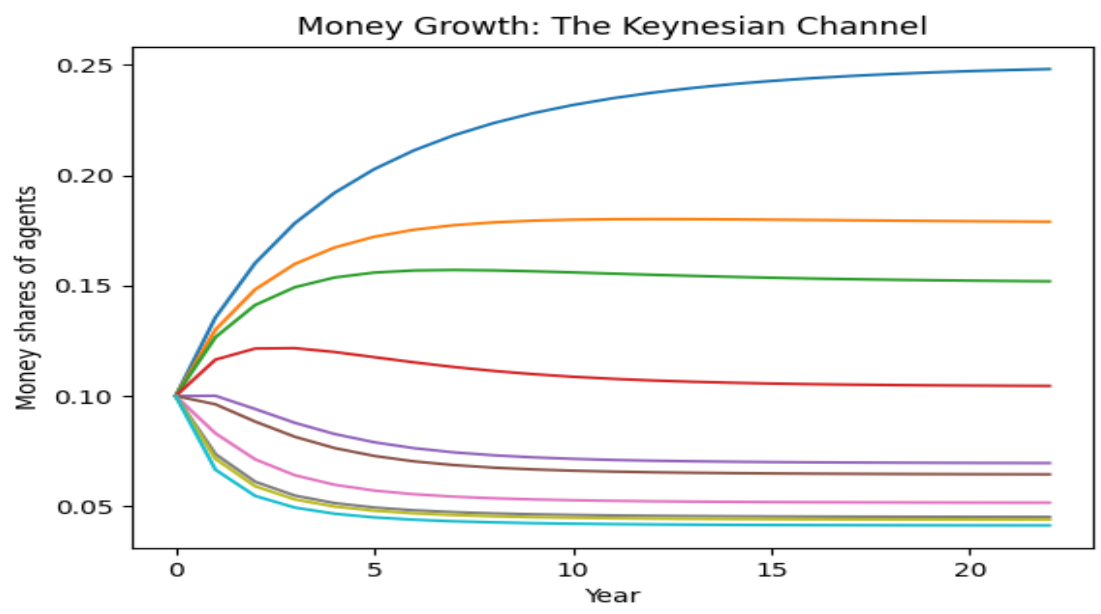

Source: authors' own elaboration 
An alternative way of money growth could potentially soften this impact. If new money were to be distributed equally across all agents in the same society as above, the wealth distribution, the velocity of money and the inflation dynamics could potentially be different.

Figure 5 presents the results of the case where money growth is distributed evenly across agents. We call this the Keynesian channel. First the growth rate of broad money is set to be 7 per cent by the monetary and fiscal authorities and then this amount of new money is deposited to the accounts of each of the 10 agents equally. This exercise is repeated at the beginning of each period.

The first observation in Figure 5 is a similar pattern with Figure 3. The wealth dispersion is inevitable because of savings heterogeneity. Yet, the wealth dispersion is reduced, both in transition and in the steady state, due to the nature of transfers in this case. For example, in year 20, the money share of the most patient agent is 26.9 per cent in the Keynesian money growth regime, while it used to be 31.1 per cent in the Fisherian regime.

A similar softening impact may well be expected for the macroeconomic variables like the velocity of money and inflation.

Figure 6 presents the transition paths for velocity and inflation to steady state. Both the initial pace of fall of velocity of money and the shortfall at its steady state value are seen to be more modest in the Keynesian case than in the Fisherian case. Therefore, the deflationary impact on the price inflation rates due to the heterogeneity in savings rates are softer in the initial transition years in the Keynesian case. Yet, eventually inflation again converges to the 7 per cent level in the steady state.

A natural question would be about the impact of different money growth rates under the two different money growth regimes. For that we ran the model numerically under money growth rates ranging from 3 per cent to 30 per cent. 
Figure 6. Velocity, inflation and wealth share of top savers: Keynesian case

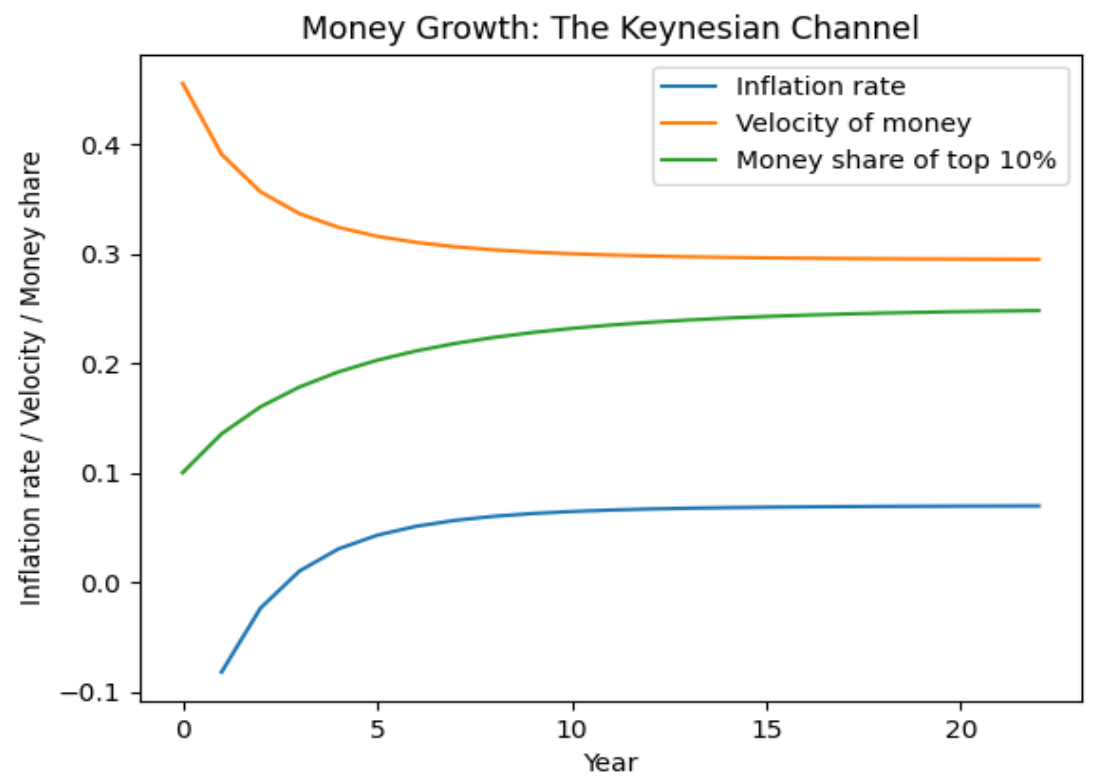

Source: authors' own elaboration

Table 1. The impact of money growth: the Fisherian channel

\begin{tabular}{|c|c|c|c|c|}
\hline $\begin{array}{c}\text { Money Growth } \\
\text { Rate (\%) }\end{array}$ & $\begin{array}{c}\text { Top 10\% Money } \\
\text { Share in Year 20 } \\
(\%)\end{array}$ & $\begin{array}{c}\text { Velocity of Money } \\
\text { in Year 0 }\end{array}$ & $\begin{array}{c}\text { Velocity of } \\
\text { Money in Year 20 }\end{array}$ & $\begin{array}{c}\text { Inflation (Geometric } \\
\text { Average Annual, \%) }\end{array}$ \\
\hline 3 & 31.1 & 0.456 & 0.256 & 0.07 \\
\hline 4 & 31.1 & 0.456 & 0.256 & 1.04 \\
\hline 7 & 31.1 & 0.456 & 0.256 & 3.96 \\
\hline 30 & 31.1 & 0.456 & 0.256 & 11.73 \\
\hline
\end{tabular}

Source: authors' own elaboration

Table 1 presents the results for the Fisherian regime. The money growth rates are taken as $3,4,7,15$ and 30 per cent in separate simulations with the same (10 agents) artificial societies. 
The money share of the top saver rises from an initial value of 10 per cent all the way up to above 30 per cent by year 20 , and continues to grow more gradually afterwards. In tandem, the money velocity falls from an initial value of 0.456 to 0.256 in year 20 . The fall in velocity keeps average inflation significantly below the money growth rates in the initial 20 years of transition.

One striking observation is the neutrality of money velocity and wealth shares visa-vis different money growth rates. The figures for these two variables follow exactly the same time path at all money growth rates. Hence the deflationary bias is also the same. This is due to the proportional nature of money growth in the Fisherian case.

\section{Table 2. The Impact of money growth: the Keynesian channel}

\begin{tabular}{|c|c|c|c|c|c|}
\hline $\begin{array}{c}\text { Money Growth } \\
\text { Rate (\%) }\end{array}$ & $\begin{array}{c}\text { Top 10\% } \\
\text { Money Share } \\
\text { in Year 20 (\%) }\end{array}$ & $\begin{array}{c}\text { Velocity of } \\
\text { Money in Year } \\
0\end{array}$ & $\begin{array}{c}\text { Velocity of } \\
\text { Money in Year } \\
20\end{array}$ & $\begin{array}{c}\text { Inflation } \\
\text { (Geometric } \\
\text { Average } \\
\text { Annual, \%) }\end{array}$ & $\begin{array}{c}\text { Extra Inflation } \\
\text { (Geometric } \\
\text { Average } \\
\text { Annual, \%) }\end{array}$ \\
\hline 3 & 27.8 & 0.456 & 0.275 & 0.43 & 0.4 \\
\hline 4 & 26.9 & 0.456 & 0.281 & 1.50 & 0.5 \\
\hline 7 & 24.7 & 0.456 & 0.295 & 4.70 & 0.7 \\
\hline 15 & 20.9 & 0.456 & 0.323 & 13.04 & 1.2 \\
\hline 30 & 17.4 & 0.456 & 0.355 & 28.39 & 1.6 \\
\hline
\end{tabular}

Source: authors' own elaboration

Table 2 presents the results for the Keynesian regime. For comparability, the money growth rates are taken as 3, 4, 7, 15 and 30 per cent, exactly the same as those in the Fisherian case. The only difference is that here is that new money is distributed evenly across all 10 agents in each period.

As expected, the wealth distribution impact of the Keynesian regime is softer. For a money growth rate of 7 per cent per annum, the money share of the highest saving agent is 26.9 per cent in contrast to 31.1 per cent in the Fisherian case. The fall in velocity and the deflationary bias is softer as well.

A second observation in the Keynesian case is one of non-neutrality with regard to different rates of broad money growth. For higher rates of money growth, the 
wealth distribution impact of heterogeneity is softer. For annual money growth rates of above 15 per cent, the wealth share of the top 10 per cent remains below 20 per cent in contrast to above 30 per cent in the Fisherian case.

Inevitably, this puts an extra inflationary pressure in the transition years. The extra average annual inflation in the first 20 years due to the Keynesian distributional effects can be as high as above 1 percentage points for double digit inflation rates, as seen on the last column of Table 2 .

\section{Concluding remarks}

Technological advances may change the way monetary and fiscal policies are conducted. The information and communication technology (ICT) revolution of the mid 70s changed the way monetary policy is conducted by the central banks. For being able to use short term interest rates as the main policy tool, a central bank had to electronically clear the interbank money market on a daily basis. This was made possible only after sufficient progress in computer technologies.

Switching to interest rates as the main policy instrument was a major structural break in economic history. Together with the central bank independence, direct monetary financing of government deficits have also come to an end. Broad money creation was left to the banking system under the guidance of the central bank in most advanced countries. This had the implication that money creation through the Fisherian channel became more dominant than the Keynesian channel of the 70s.

Likewise, the recent wave of technological revolution in ICT which enable the continuous storage and use of big data has important implications on financial technologies, the so called fintech. The central banks faced with an intense completion from private sector companies in issuing their own unbacked currencies, felt the need to innovate and came up with the idea of Central Bank Digital Currency (CBDC). The merits of access by all citizens to 'account based' CBDCs is summarised in the 2021 annual report of the Bank for International Settlements (BIS 2021: Chapter 3). This idea will likely trigger a healthy debate on the way monetary and fiscal policies are conducted. 
Technological advances may also change the way monetary and fiscal policies are analysed. Heterogeneity has been a technical difficulty that most macroeconomist have avoided over the last four decades and have remained in the convenience of the representative agent paradigm. Yet, in some cases there are important macroeconomic insights to be gained from heterogeneous agent models that are absent in representative agent models (Kirman 1992; Domanski et al. 2016).

Agent Based Modelling (ABM) is one such strong tool of analysis (Arthur 1991). Although in most cases basic economic insights are valid, the experimental and quantitative aspects of $\mathrm{ABM}$ have great potential uses to inform and enrich policy design deliberations. ABMs have already been applied to finance (Lebaron 2001) and to macroeconomics (Turrel 2016). The most obvious practical use of ABMs is to study agent heterogeneity and the resulting income and wealth dispersion (Asano et al. 2019). Our simulation model in this paper can be considered as the simple building block of such a sophisticated ABM model. Future versions of our model may incorporate adaptive behaviour of agents, like learning the optimal savings behaviour over time (see for example Basci 1999). Introducing real assets in addition to money and hence real physical investments would be another extension of the current version.

In this paper we have demonstrated by means of a simple monetary model with heterogeneous consumers, the benefits and costs of two alternative money growth regimes, in order to contribute to the recently revived debate on the use of 'helicopter money'. Our results show that more inclusive ways of money growth (potentially with the use of CBDCs) may have some social stability benefits in addition to some economic stimulus benefits. Yet, the extra inflationary impact of such a regime has to be taken into consideration. The post-pandemic new policy mix needs to be carefully managed if it is to remain both inclusive and non-inflationary. 


\section{Bibliography}

Arthur W.B. (1991), Designing Economic Agents that Act Like Human Agents. A Behavioural Approach to Bounded Rationality, “American Economic Review”, vol. 81 no. 2, pp. 353-359.

Asano Y., Kolp J.J., Heitzig J., Farmer J.D. (2019), Emergent Inequality and Endogenous Dynamics in a Simple Behavioural Economic Model, "INET Oxford Working Paper", no. 2019-11.

Basci E. (1999), Learning by Imitation, "Journal of Economic Dynamics and Control", vol. 25 no. 9, pp. 1569-1585.

Basci S., Gherbi, T. (2020), Demand Deficiency, Money Velocity and Heterogeneity, "Central European Review of Economics and Management", vol. 4 no. 2, pp. 137-153.

Basci E., Basci S. (2021), Demand Deficiency in G7 Countries, "International Econometric Review, Economics of the 21 st Century", vol. 13 no. 3, pp. 59-70.

Bernanke B.S. (2002), Deflation: Making Sure “It" Doesn't Happen Here. Remarks before the National Economists Club, Washington, D.C., November 21, https://www.federalreserve.gov/BOARDDOCS/Speeches/2002/20021121/default.htm\#f8 [02.12.2021].

BIS (2021), CBDCs: an Opportunity for the Monetary System, Bank for International Settlements Annual Report, Basel, https://www.bis.org/publ/arpdf/ar2021e3.htm [02.12.2021].

Blanchard O. (2021), In Defense of Concerns over the \$1.9 Trillion Relief Plan, Peterson Institute for International Economics, February 18, https://www.piie.com/blogs/realtime-economic-issueswatch/defense-concerns-over-19-trillion-relief-plan [02.07.2021].

Carroll C.D., Crawley E., Slacalek J., White M.N. (2021), Modelling the Consumption Response to the CARES Act, "International Journal of Central Banking", vol. 17 no. 1, pp. 107-141.

Carroll C.D., Slacalek J., Tokuoka K., White M.N. (2017), The Distribution of Wealth and the Marginal Propensity to Consume, "Quantitative Economics", vol. 8 no. 3, pp. 977-1020.

Domanski D., Scatigna M., Zabai A. (2016), Wealth Inequality and Monetary Policy, "BIS Quarterly Review", March, pp. 45-64.

English B., Forbes K., Ubide Á (eds.) (2021), Monetary Policy and Central Banking in the Covid Era, CEPR Press, https://voxeu.org/content/monetary-policy-and-central-banking-covid-era [02.12.2021].

Fisher I. (1930), The Theory of Interest, 1st ed., The Macmillan Co., New York.

Galí J. (2020a), The Effects of a Money-Financed Fiscal Stimulus, "Journal of Monetary Economics", vol. 115, pp. 1-19.

Galí J. (2020b), Helicopter Money: The Time is Now", VoxEU.org, March 17, https://voxeu.org/article/helicopter-money-time-now [02.12.2021].

Goodhart Ch. (2020), Inflation after the Pandemic: Theory and Practice, VoxEU, June 13, https://voxeu.org/article/inflation-after-pandemic-theory-and-practice [02.12.2021]. 


\section{ERDEM BASCI, SIDIKA BASCI, TAHAR GHERBY}

Jilek J., Matousek R. (2010), Money in the Modern World, Peter Lang, Frankfurt.

Karamcheva N. (2016), Trends in Family Wealth, Congressional Budget Office, https://www.cbo.gov/publication/51846 [02.12.2021].

Kirman A.P. (1992), Whom or What Does the Representative Individual Represent?, "Journal of Economic Perspectives", vol. 6 no. 2, pp. 117-136.

Lebaron B. (2001), A Builder's Guide to Agent-Based Financial Markets, ,'Quantitative Finance", vol. 1 no. 2, pp. 254-261.

Martin P., Monnet E., Ragot X., Renault T., Savatier B. (2021), Helicopter Money as a Last Resort Contingent Policy, VoxEU, CEPR, April 5, https://voxeu.org/article/helicopter-money-last-resortcontingent-policy [02.12.2021].

McLeay M., Radia A., Thomas R. (2014), Money Creation in the Modern Economy, "Bank of England Quarterly Bulletin”, vol. 54 no. 1, https://www.bankofengland.co.uk/quarterly-bulletin/2014/q1/moneycreation-in-the-modern-economy [02.12.2021].

Summers L. (2021), The Biden Stimulus Is Admirably Ambitious. But It Brings Some Big Risks, too. Opinion, The Washington Post, February 7, https:/www.washingtonpost.com/opinions/2021/02/04/ larry-summers-biden-covid-stimulus/ [02.12.2021].

Turrell A. (2016), Agent-Based Models: Understanding the Economy from Bottom-up, "Bank of England Quarterly Bulletin”, vol. Q4, pp. 173-188. 